\title{
選択的 $\operatorname{IgM}$ 欠損症 10 例における細胞レベルの病態解析
}

\author{
井上 孝利・石橋 大海・工藤 二 郎 \\ 白 浜 正 文・仁 保 喜 之・大久保 英雄*
}

Jpn. J. Clin. Immun., 11(3):236 243, 1988.

\section{Functional and phenotypical analysis of the lymphocytes in 10 patients with selective IgM deficiency}

\author{
Takatoshi Inoue, Hiromi Ishibashi, Jiro Kudo \\ Masafumi Shirahama, Yoshiyuki Niho and Hideo Okubo* \\ The First Department of Internal Medicine, Faculty of Medicine, Kyushu University \\ *Kitakyushu Municipipal Hospital
}

\section{【Summary】}

Ten patients with selective IgM deficiency (SIgMD) were studied for cell surface immunoglobulin, immunophenotype of $\mathrm{T}$ lymphocytes and immunoglobulin synthesis in vitro by peripheral blood lymphocytes. Serum IgM levels were less than $25 \mathrm{mg} / \mathrm{dl}$, while IgA, IgG, and $\operatorname{IgD}$ were within normal levels. Ten patients had respiratory or urinary tract infections, three were diagnosed as having systemic lupus erythematosus (SLE) and one as rheumatoid arthritis (RA). Surface immunoglobulins were almost within normal range except two cases who had very low surface immunoglobulins. However, normal values were detected after 7 days of culture in the presence of normal $\mathrm{T}$ lymphocytes with Pokeweed mitogen. E rosett counts were normal in all patients. As for immunophenotype of $\mathrm{T}$ lymphocytes, OKT 4/OKT 8 ratios were low in all the cases. Analysis of lymphocyte function for immunoglobulin synthesis in vitro, using a co-culture of counterpart $\mathbf{T}$ and $\mathbf{B}$ cells from healthy individuals and patients with SIgMD, revealed the excessive function of IgM specific suppressor $T$ lymphocytes. These results suggest that the increased function of IgM specific suppressor $\mathrm{T}$ cells was responsible for the $\operatorname{lgM}$ deficiency in all ten cases.

Key words : selective IgM deficiency, suppressor $\mathrm{T}$ cell, systemic lupus erythematosus, monoclonal antibody, immunoglobulin synthesis in vitro 


\section{【概 要】}

10 例の選択的 IgM 欠損症について, リンパ球表面の免疫グロブリン, Eロゼット形成細胞数，モノクローナル抗 体による表面マーカーの検索と合わせて, in vitro における免疫グロブリン産生能を検索した. 血清 IgM 濃度は全

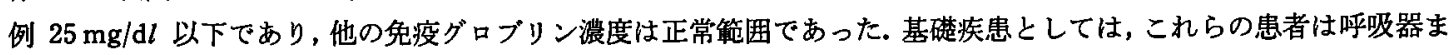
たは尿路感染症を発症しており，3例に全身性エリテマトーデス（SLE），1例に慢性関節リウマチ（RA）がみられ た. リンパ球表面免疫グロブリンのうち, IgA，IgD，IgG，IgM は 2 例を除いて正常範囲にあり，この 2 例はすへて のリンパ球表面免疫グロブリンが減少していた．Eロゼット形成率はすべて正常であった．モノクローナル抗体によ る表面マーカーの検索では, OKT 4 が 2 例に低く, OKT 8 が 3 例に高く, 全体として OKT 4/OKT 8 比が低値であ った. in vitro での免疫グロブリン合成は，全例 $\operatorname{IgA}, \operatorname{IgG}$ 産生は正常で $\operatorname{IgM}$ 産生のみ著明に低下していた，患者 と健常者の $\mathrm{T}, \mathrm{B}$ 細胞を組み合わせて免疫グロブリン産生を検討した成績では，患者のB細胞执よ゙ helper T 細胞 異常はなく, IgM 特異的 suppressor $\mathrm{T}$ 細胞の活性上昇が証明された. これら10例の IgM 欠損は, IgM 特異的サ プレッサーT 細胞の機能六進によることが示唆される.

\section{I. 緒 言}

免疫不全症の中で比較的頻度が高い選択的 IgA 欠損 症 (selective IgA deficiency, 以下 IgA 欠損症と略 す）は，しばしば上気道感染や消化管感染を繰り返し， 自己免疫疾患や悪性腫陽を合併しやすいことが報告され ている1. われわれは, IgA 欠損症のリンパ球を培養し， in vitro の系に扔ける免疫グロブリンの生合成を測定す ることによって, IgA 欠損症の病態が，(1) B 細胞の内的 欠損 (intrinsic defect), (2) IgA 特異的 helper $\mathrm{T}$ 細胞 の活性低下, (3) IgA 特異的 suppressor $\mathrm{T}$ 細胞の活性上 昇, (4) B 細胞異常と suppressor $\mathrm{T}$ 細胞活性上昇の合併 の 4 種類に分類されることを明らかにした ${ }^{2)}$.

一方，選択的 IgM 欠損症 (selective IgM deficiency， 以下 IgM 欠損症と略す) は, community health study で $0.03 \%$ 以下と頻度が低く ${ }^{3)}$, その病態として helper T 細胞の活性低下 ${ }^{3)}$ や, suppressor $\mathrm{T}$ 紐胞活性の増加な どの症例報告 ${ }^{4 \sim 7)}$ があるが, 従来まとまった数の報 告が ないため詳細は明らかでない. 本研究においては, 感染 症を契機として診断された 10 例の IgM 久損症につい て，その病態を明らかにすることを目的とし，リンパ球 表面免疫グロブリン, $\mathrm{E}$ ロゼット形成能, モノクローナ ル抗体による表面マーカーと合わせて, in vitro におけ る免疫グロブリン産生能を調べた.

\section{II. 方 法}

対象患者は 10 例, 年龄は 29 歳から 73 歳をで, 平均 49 歳, 男女比は 1 対 1 で,すべて尿路感染, 髄膜炎, 肺炎な どを発症した入院患者であった（表 1). 全症例を 2 年以 上にわたり追跡し，その血清 IgM 濃度が常に $25 \mathrm{mg} / \mathrm{d} l$
未満 (正常值 80 300 mg/d $l$ ) で IgA, IgG 濃度は正常 範用にあることが証明されている. 全身性エリテマトー デス（SLE） 3 例, 慢性関節リウマチ（RA） 1 例, 胃の 平滑筋肉腫 1 例, 尿路感染 5 例を合併していた.

\section{1.リンパ球の分離, 培養}

リンパ球はヘパリン加末梢血から, Ficoll-Conray に よる比重遠沈法8)により分離した. マクロファージ除去 は、このリンパ球分画をプラスチック製培荃試験管に 30 分培荃して, 接着細胞を除く方法で行った. $\mathrm{T}$ 細胞は neuraminidase処理ヒツジ赤血球を用いた E ロゼット法9) により分離した. また, リンパ球から $\mathrm{T}$ 細胞を除いた分 画を B 細胞として用いた. 患者および健常者の T 細胞， $\mathrm{B}$ 細胞をおのおの終竖度 $5 \times 10^{5} / \mathrm{ml}$ ( $\mathrm{T}: \mathrm{B}$ 比=1:1) で組み合わせ, 7 日間, $37^{\circ} \mathrm{C}, 5 \% \mathrm{CO}_{2}$ 下で triplicate に て培養した。

培地は, $10 \%$ ウシ胎児血清 (FCS), streptomycin (50 $\mu \mathrm{g} / \mathrm{m} l)$ を含んだ RPMI 1640 を用い, Pokeweed mitogen (PWM, $10 \mu \mathrm{g} / \mathrm{m} l), 2$-mercaptoethanol $\left(5 \times 10^{-5}\right.$ M) を添加した. また, $\mathrm{T}$ 細胞の一部は $2,000 \mathrm{rad} の \mathrm{X}$ 線照射を行い, suppressor $\mathbf{T}$ 細胞の活性を消失させて用 いた.

\section{2.リンパ球表面の兔疫グロブリン}

螢光抗体直接法を用いた. すなわち，FITC を結合し た家鬼の抗ヒト IgA, IgD, IgG, IgM 抗体 $0.01 \mathrm{ml}$ を gelatin-Veronal buffer (GVB) 下で $1 \times 10^{5} / \mathrm{m} l$ のリン パ球に加え, 30 分インキュベートし，GVB で洗浄後, Zeiss 螢光顕微鏡にて 500 個以上の細胞を検索した. 
表 1 Serum immunoglobulin level and complications

\begin{tabular}{|c|c|c|c|c|c|c|c|c|c|}
\hline \multirow{2}{*}{ Patient } & \multirow{2}{*}{ Age } & \multirow{2}{*}{ Sex } & \multirow{2}{*}{$\begin{array}{c}\text { IgG } \\
(\mathrm{mg} / \mathrm{d} l)\end{array}$} & \multirow{2}{*}{$\begin{array}{c}\operatorname{IgM} \\
(\mathrm{mg} / \mathrm{d} l)\end{array}$} & \multirow{2}{*}{$\begin{array}{c}\operatorname{IgA} \\
(\mathrm{mg} / \mathrm{d} l)\end{array}$} & \multirow{2}{*}{$\begin{array}{c}\mathrm{IgD} \\
(\mathrm{mg} / \mathrm{d} l)\end{array}$} & \multirow{2}{*}{$\begin{array}{c}\operatorname{IgE} \\
(\mathrm{IU} / \mathrm{m} l)\end{array}$} & \multicolumn{2}{|c|}{ Complications $^{\mathrm{a}}$} \\
\hline & & & & & & & & $\begin{array}{l}\text { underlying } \\
\text { disease }\end{array}$ & $\begin{array}{l}\text { accompanying } \\
\text { infection }\end{array}$ \\
\hline 1. Y.I. & 29 & $\mathrm{~F}$ & 1,597 & 25 & 203 & 3 & 840 & SLE & RTI, UTI \\
\hline 2. K.S. & 30 & M & 936 & 6 & 221 & 4 & 175 & SLE & UTI \\
\hline 3. U.I. & 39 & $\mathrm{~F}$ & 947 & 6 & 176 & 5 & 303 & SLE & Meningitis \\
\hline 4. C.Y. & 42 & M & 3,798 & 10 & 590 & ND & 1,300 & & UȚI \\
\hline 5. K.K. & 48 & M & 1,641 & 10 & 243 & 2 & 154 & & Pneumonia \\
\hline 6. M.S. & 51 & M & 850 & 8 & 253 & ND & ND & $\begin{array}{l}\text { Leiomyosarcoma } \\
\text { (stomach) }\end{array}$ & \\
\hline 7. A.H. & 53 & $F$ & 2,159 & 17 & 612 & 2 & 30 & RA & UTI \\
\hline 8. M.F. & 58 & $\mathrm{M}$ & 972 & 20 & 93 & 5 & 208 & & UTI, Tbc (lung) \\
\hline 9. S.M. & 71 & $\mathrm{~F}$ & 1,726 & 11 & 412 & 2 & 130 & & UTI, Pneumonia \\
\hline 10. T.N. & 73 & $\mathrm{~F}$ & 1,248 & 14 & 206 & 0 & 30 & & UTI, RTI \\
\hline \multicolumn{3}{|c|}{$\begin{array}{l}\text { Control } \\
(\text { mean } \pm \mathrm{SD})\end{array}$} & $\begin{array}{c}1,594 \\
\pm \\
314\end{array}$ & $\begin{array}{l}175 \\
\pm \\
65\end{array}$ & $\begin{array}{l}265 \\
\pm \\
92\end{array}$ & $\begin{array}{l}2.65 \\
\pm \\
2.09\end{array}$ & $\begin{array}{l}143.6 \\
\pm \\
92.0\end{array}$ & & \\
\hline
\end{tabular}

$\mathrm{a}$ : UTI ; urinary tract infections-cystitis, pyelonephritis, RTI ; respiratory tract infections-pharyngitis, bronchitis, Tbc ; tuberculosis, SLE ; systemic lupus erythematosus, RA ; rheumatoid arthritis, ND ; not done.

\section{IgA，IgG，IgM の測定}

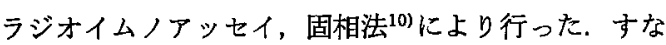
わち，ポリスチレンチューブに抗ヒト Ig（抗 Fc $\alpha ， r$, ル)抗体をコーティングし，これにサンプルと標準液を加 え，傾斜したラックで一晚回転させた. ついで, 0.5\% ウ シ血清アルブミンを含む borate-buffered saline (BSAsaline) で 3 回洗浄後, クロラミン T 法で ${ }^{125} \mathrm{I}$ をラベル した抗七ト $\mathrm{Fab}$ 抗体を加えた. 一晚 (約 8 時間) 回転 しながら抗原一抗体反応を完了させた後, BSA-saline で 5 回洗浄し，ポリスチレンチューブの放射活性を $\gamma$ ーカウ ンターで測定した.

\section{IgA, IgG, IgM, 抗 Fab, 抗 Fca, $\gamma, \mu$ 抗体の 精製}

IgA は1例の IgA 骨髄腫 ${ }^{11)}$, IgG はプールしたヒト

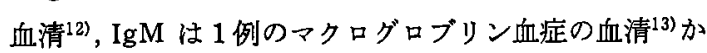
ら精製した。抗 $\mathrm{Fab}$ 抗体の分離 ${ }^{14)}$ は, IgG をペプシン 処理（酵素：基質は重量比で $1: 50$ ) 後, Sephadex G$150(0.02 \mathrm{M}$ Tris buffer-0.3 M NaCl, pH 8.0) にてゲ ルクロマトグラフィーによった. Fcr 抗体は, IgG-conjugated Sepharose 4B gel column を通し, さらに F $\left(\mathrm{ab}^{\prime}\right)_{2}$-conjugated Sepharose 4B gel column を通過した 分画より得た. 抗 $F c \alpha$ 抗体, 抗 $F c \mu$ 抗体は，おの沶の 抗 Fab 抗体を除いた後, IgA, IgM-conjugated Sepharose 4B gel column 家用いて得た.

\section{5. モノクローナル抗体を用いたリンパ球表面マーカ 一の検索}

T細胞表面マーカーに対するモノクローナル抗体 OK'T 4, OKT 8, の検索は, Ortho. Spectrum III を用い て行った.

\section{III. 結 果}

\section{1. 血清免疫グロブリンおよび合併症（表 1)}

血清 IgM は 10 例全例, 観察期間 2 年以上にわたり 25 $\mathrm{mg} / \mathrm{d} l$ 末満であった. 3 例に IgA, IgE レベルが高值で あったが，他の7例では IgA，IgD, IgE, IgGいずれも すへて正常範囲であった。基礎疾患として 3 例 (症例 1 , 2,3) が SLE，1例 (症例 7) が RA, 1例 (症例 6) が 胃の平滑箭肉腫をもち，8例が尿路感染，5例が気道感 染， 1 例（症例 3) が髄膜炎を合併していた.

\section{2. リンパ球表面マーカー（表 2)}

表面免疫グロブリンは 8 例にお゙いて正常パターンであ った。２例は，すべての表面免疫グロブリンが低值であ った，Eロゼット形成率は，全例正常であった， T 細胞 に対するモノクローナル抗体を用いたりンパ球表面マー カーの検索では，OKT 4 が 2 例で低く，OKT 8 は全体 的に高く，とくに 3 例で高かった. したがって, OKT 4/ OKT 8 比は全例で低值であった. 
表 2 Surface markers on peripheral blood lymphocytes

\begin{tabular}{|c|c|c|c|c|c|c|c|c|c|c|c|c|c|}
\hline \multirow{2}{*}{ Case } & \multirow{2}{*}{ Age } & \multicolumn{4}{|c|}{ SmIg on PBL (\%) } & \multicolumn{4}{|c|}{ SmIg'on stimulated PBL(\%) } & \multicolumn{4}{|c|}{$\mathrm{T}$ cell markers $(\%)$} \\
\hline & & IgG & IgM & IgA & IgD & IgG & IgM & IgA & $\operatorname{IgD}$ & E-RFC & OKT 4 & OKT 8 & OKT $4 /$ OKT 8 \\
\hline 1. Y.I. & 29 & 8.6 & 2.1 & 5.1 & 4.3 & 17.2 & 14.8 & 9.6 & 8.5 & 74 & 21.9 & 53.1 & 0.4 \\
\hline 2. K.S. & 30 & 6.4 & 5.7 & 4.2 & 3.9 & 11.2 & 9.4 & 6.8 & 5.2 & 75 & 19.8 & 47.4 & 0.4 \\
\hline 3. U. I . & 39 & 6.2 & 2.1 & 4.8 & 3.6 & 11.3 & 10.8 & 10.6 & 7.9 & 77 & 21.8 & 44.9 & 0.5 \\
\hline 4. C.Y. & 42 & 13.4 & 0.1 & 8.5 & 6.9 & 16.4 & 12.7 & 10.5 & 7.3 & 63 & 12.8 & 30.9 & 0.4 \\
\hline 5. K.K. & 48 & 6.6 & 11.0 & 6.6 & 2.4 & 13.4 & 22.7 & 11.2 & 10.1 & 56 & 8.0 & 33.7 & 0.2 \\
\hline 6. M.S. & 51 & ND & ND & ND & ND & ND & ND & ND & ND & $\mathrm{ND}$ & ND & ND & ND \\
\hline 7. A.H. & 53 & 1.0 & 1.0 & 0.0 & 2.0 & 23.1 & 24.6 & 10.1 & 9.1 & 88 & 36.1 & 44.4 & 0.8 \\
\hline 8. M.F. & 58 & 5.1 & 9.4 & 4.9 & 3.7 & 13.9 & 24.6 & 10.1 & 9.3 & 72 & 35.2 & 27.5 & 1.3 \\
\hline 9. S.M. & 71 & 11.1 & 14.7 & 7.6 & 6.6 & 11.7 & 34.7 & 7.6 & 4.6 & 74 & 22.1 & 57.5 & 0.4 \\
\hline 10. T.N. & 73 & 4.9 & 0.2 & 1.2 & 0.0 & 30.1 & 8.8 & 10.7 & 3.6 & 84 & 29.4 & 55.3 & 0.5 \\
\hline $\begin{array}{l}\text { Control } \\
\text { (mean } \pm \mathrm{SL}\end{array}$ & & $\begin{array}{l}8.3 \\
\pm \\
1.4\end{array}$ & $\begin{array}{l}6.5 \\
\pm \\
1.0\end{array}$ & $\begin{array}{l}3.8 \\
\pm \\
1.0\end{array}$ & $\begin{array}{l}4.0 \\
\pm \\
0.9\end{array}$ & $\begin{array}{c}16.5 \\
\pm \\
5.8\end{array}$ & $\begin{array}{c}16.5 \\
\pm \\
4.8\end{array}$ & $\begin{array}{l}6.5 \\
\pm \\
2.3\end{array}$ & $\begin{array}{l}5.5 \\
\pm \\
2.8\end{array}$ & $\begin{array}{l}67.3 \\
\pm \\
4.0\end{array}$ & $\begin{array}{c}38.3 \\
\pm \\
7.9\end{array}$ & $\begin{array}{c}29.2 \\
\pm \\
9.0\end{array}$ & $\begin{array}{l}1.5 \\
\pm \\
0.7\end{array}$ \\
\hline
\end{tabular}

Surface Ig on PBL were expressed as a percentage of the total cells. PBL from the patients with SIgMD were cultured in RPMI 1640 with PWM for 7 days and surface Ig on the cells was determined. PBL ; peripheral blood lymphocytes, E-RFC ; E-rosette forming cells, ND ; not done, SD ; standard deviation, SIgMD ; selective IgM deficiency.

\section{In vitro での免疫グロブリン生合成}

(1) 健常者の免疫グロプリン合成量は, リンパ球 $5 \times$ $10^{5}$ 個を 7 日間培養した培地 $1 \mathrm{~m} l$ あたりの濃度でみる と IgA $1,763 \pm 278 \mathrm{ng}, \operatorname{IgG} 2,598 \pm 296 \mathrm{ng}, \operatorname{IgM} 2,349 \pm$ $276 \mathrm{ng}$ であった（表 3).

(2) $\operatorname{IgM}$ 欠損患者では IgA と IgG の産生は健常者 と同等であったが, IgM の産生は全例においてほとんど みられなかった（表 3).

(3) 健常者 $\mathrm{B}$ 細胞と患者 $\mathrm{T}$ 細胞を組み合わせた場合 （表 4, および図 1, NB+PT）の免疫グロブリン産生を みると，IgM 産生は著明に低下していたが，IgA，IgG 産生は正常であった. 患者 $\mathrm{T}$ 細胞を $\mathrm{X}$ 線照射後，健常者 B 細胞と組み合わせると，正常量の IgM 産生がみられ $\left(\mathrm{NB}+\mathrm{PT}^{*}\right)$, また患者 $\mathrm{B}$ 細胞と健常者 $\mathrm{T}$ 細胞の組み合わ せ $(\mathrm{PB}+\mathrm{NT})$ でも正常量の IgM が産生された（表 4, 図 1).

$\mathrm{B}$ 細胞の免疫グロブリン産生に及ぼす $\mathrm{T}$ 細胞機能の量 依存性をみる目的で, 一定数の健常者 B 細胞 $\left(5 \times 10^{5}\right)$ $\mathrm{m} l$ ) に各種濃度の $\mathrm{X}$ 線照射した患者 $\mathrm{T}$ 細胞を加えると， IgA，IgG，IgM は T 細胞濃度が $15 \times 10^{5} / \mathrm{m} l$ までは量 依存性に産生の増加がみられた (図 2). しかし，X線照 射しない患者 $\mathrm{T}$ 細胞を加えた場合には $\mathrm{T}$ 細胞の量依存 性に IgA, IgG の産生増加がみられたが, IgM 産生は T細胞濃度に関係なく著明に低下していた.
表 3 Amount of immunoglobulin synthesis in vitro

\begin{tabular}{cccc}
\hline Patient & $\operatorname{IgG}(\mathrm{ng} / \mathrm{m} l)$ & $\operatorname{IgM}(\mathrm{ng} / \mathrm{m} l)$ & $\operatorname{IgA}(\mathrm{ng} / \mathrm{ml})$ \\
\hline 1. Y.I. & $2,788 \pm 124$ & $638 \pm 88$ & $1,863 \pm 159$ \\
2. K.S. & $2,513 \pm 88$ & $113 \pm 53$ & $2,000 \pm 141$ \\
3. U.I. & $2,388 \pm 316$ & $95 \pm 48$ & $1,683 \pm 268$ \\
4. C.Y. & $2,550 \pm 278$ & $259 \pm 88$ & $1,758 \pm 226$ \\
5. K.K. & $2,458 \pm 202$ & $292 \pm 38$ & $1,808 \pm 88$ \\
6. M.S. & $2,600 \pm 313$ & $350 \pm 88$ & $1,933 \pm 213$ \\
7. A.H. & $2,575 \pm 125$ & $167 \pm 76$ & $1,808 \pm 163$ \\
8. M.F. & $2,500 \pm 205$ & $450 \pm 205$ & $1,925 \pm 115$ \\
9. S.M. & $2,758 \pm 201$ & $200 \pm 87$ & $1,750 \pm 189$ \\
10. T.N. & $2,500 \pm 132$ & $342 \pm 113$ & $1,583 \pm 138$ \\
\hline Control & $2,598 \pm 296$ & $2,349 \pm 276$ & $1,763 \pm 278$ \\
\hline
\end{tabular}

$B$ and $T$ cells from patients with SIgMD were co-cultured in RPMI 1640 with PWM for 7 days and Ig secreted in the culture media were measured in triplicates by solid phase radio-immunoassay.

\section{IV. 考 案}

感染症を契機として入院した患者と膠原病患者の中か ら免疫グロブリンのスクリーニングによって 10 例の $\operatorname{IgM}$ 欠損症を発見した. IgM 欠損症の合併感染症は尿 路, 気道の感染症が多かったが, 本症に細菌, ウイルス の感染が高頻度にみられたことは従来の報告5,15 17) どお りであり, IgM が IgG, IgA とともに感染防御に大き 
表 4 IgM synthesis in vitro

\begin{tabular}{lcccccccc}
\hline Case & $\mathrm{NB}+\mathrm{NT}$ & $\mathrm{NB}+\mathrm{NT}^{*}$ & $\mathrm{NB}+\mathrm{PT}$ & $\mathrm{NB}+\mathrm{PT}^{*}$ & $\mathrm{~PB}+\mathrm{PT}$ & $\mathrm{PB}+\mathrm{PT}^{*}$ & $\mathrm{~PB}+\mathrm{NT}^{2}$ & $\mathrm{~PB}+\mathrm{NT}^{*}$ \\
\hline 1. Y.I. & $2,625 \pm 212$ & $2,638 \pm 124$ & $563 \pm 53$ & $2,588 \pm 88$ & $638 \pm 88$ & $2,600 \pm 141$ & $2,563 \pm 159$ & $2,600 \pm 177$ \\
2. K.S. & $2,263 \pm 88$ & $2,238 \pm 159$ & $163 \pm 53$ & $2,150 \pm 106$ & $113 \pm 53$ & $2,238 \pm 124$ & $2,125 \pm 106$ & $2,125 \pm 150$ \\
3. U.I. & $2,133 \pm 243$ & $2,250 \pm 284$ & $113 \pm 88$ & $2,175 \pm 229$ & $95 \pm 48$ & $2,325 \pm 267$ & $2,175 \pm 260$ & $2,300 \pm 225$ \\
4. C.Y. & $2,450 \pm 278$ & $2,525 \pm 265$ & $334 \pm 52$ & $2,377 \pm 319$ & $259 \pm 88$ & $2,404 \pm 256$ & $2,488 \pm 319$ & $2,550 \pm 336$ \\
5. K.K. & $2,333 \pm 72$ & $2,333 \pm 247$ & $475 \pm 198$ & $2,150 \pm 214$ & $292 \pm 38$ & $2,308 \pm 227$ & $2,333 \pm 227$ & $2,325 \pm 254$ \\
6. M.S. & $1,958 \pm 226$ & $2,083 \pm 288$ & $358 \pm 113$ & $2,050 \pm 325$ & $350 \pm 88$ & $2,067 \pm 288$ & $2,058 \pm 204$ & $2,075 \pm 232$ \\
7. A.H. & $2,008 \pm 38$ & $2,125 \pm 229$ & $308 \pm 138$ & $1,950 \pm 214$ & $167 \pm 76$ & $1,783 \pm 252$ & $1,992 \pm 138$ & $2,017 \pm 142$ \\
8. M.F. & $2,250 \pm 115$ & $2,250 \pm 238$ & $458 \pm 113$ & $2,050 \pm 175$ & $450 \pm 205$ & $2,233 \pm 184$ & $2,233 \pm 202$ & $2,225 \pm 254$ \\
9. S.M. & $2,508 \pm 201$ & $2,500 \pm 278$ & $417 \pm 101$ & $2,458 \pm 250$ & $200 \pm 87$ & $1,908 \pm 580$ & $2,325 \pm 270$ & $2,342 \pm 300$ \\
10. T.N. $1,875 \pm 189$ & $1,858 \pm 126$ & $433 \pm 166$ & $1,800 \pm 139$ & $342 \pm 113$ & $1,850 \pm 115$ & $1,742 \pm 118$ & $1,758 \pm 128$ \\
\hline
\end{tabular}

PWM induced IgM synthesis by lymphocytes from normal donor and patients with SIgMD.. B or T cells were cocultured with counterpart lymphocytes for 7 days and IgM secreted in the culture media were measured by solid phase radioimmunoassay. All data are expressed in terms of $\operatorname{IgM} \mathrm{ng} / \mathrm{m} l / 5 \times 10^{5}$ cells (mean \pm S.D.). $\mathrm{N}$; normal donor, $\mathrm{P}$; patient with SIgMD, $\mathrm{B} ; \mathrm{B}$ cells, $\mathrm{T} ; \mathrm{T}$ cells, $\mathrm{T}^{*}$; irradiated $\mathrm{T}$ cells.
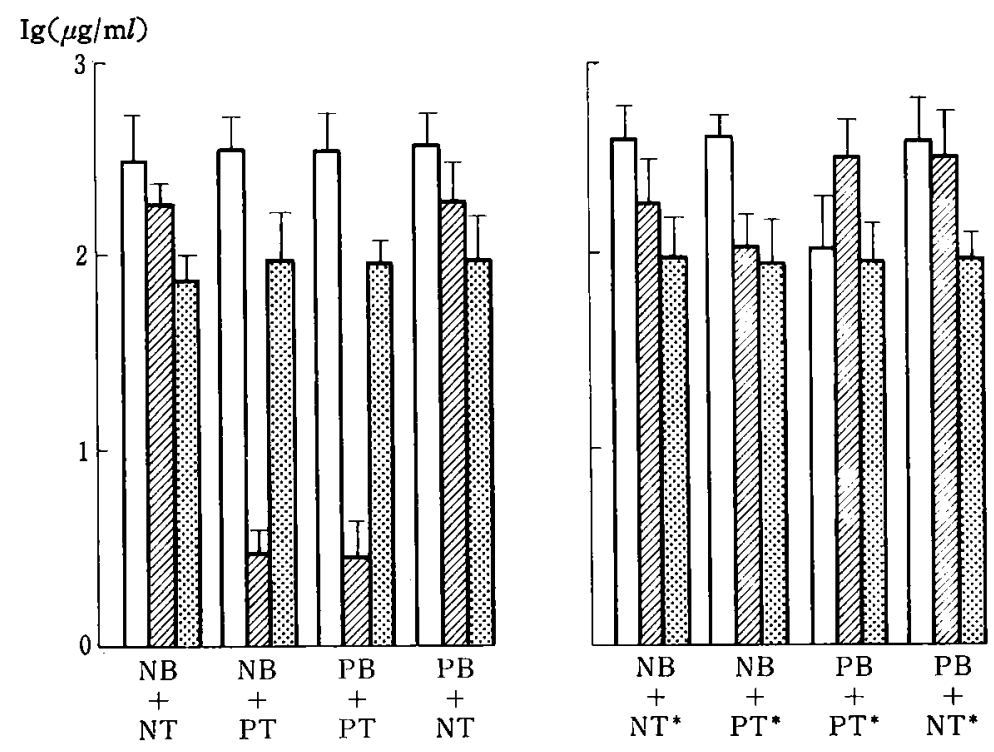

IgG; $\square, \operatorname{IgM} ; \square$, IgA; $;, \mathrm{T}^{*}$; irradiated T cells,

$P$; patient, $N$; normal donor.

图 1 PWM stimulated Ig production by co-culture of $\mathrm{B}$ cells $\left(5 \times 10^{5} /\right.$ $\mathrm{m} l$ ) from normal donor (NB, NT) and patient M.F. (PB, PT)

な役割を果たしていることが推定される. 基礎疾患とし て, SLE 3 例と RA 1例, 計 4 例の膠原病がみられた。

IgM をスクリーニングしたと同一の SLE グループ 267 例中 IgA 欠損は 2 例であること, 265,000 人の健常者の スクリーニングで IgA 欠損症が 16 例発見されたことか ら考えると膠原病患者に IgA 欠損あるいは IgM 欠損 が合併する覑度はきわめて高いことが判明した，一方， 健常者のスクリーニングでは IgM 欠損は $0.03 \%$ と報告
されている3).

$\operatorname{IgM}$ 欠損症のこれら10例において，血清 IgM が低 いにむかかわらずリンパ球表面 IgM がほとんど正常で あったことは従来の報告 ${ }^{15 \sim 18)}$ と一致した. 2 例 (AH, TN)は，すべてのリンパ球表面免疫グロブリンが低值で あったが，患者 $\mathrm{B}$ 細胞と健常者 $\mathrm{T}$ 細胞を組み合わせた培 養 7 日目には，リンパ球表面に IgM, IgA, IgD, IgG が 証明できた。このことは，正常 T細胞の存在下では患者 
B細胞㤋分化可能であることを示しているものと考えら れる. Eロゼット形成率はすべての症例で正常であり, T細胞の絶対数の增加はないことが判明したが，これは 従来の報告 ${ }^{15 \sim 18)}$ と一致するものである.

モノクローナル抗体によるリンパ球表面マーカーの検 索では，OKT 8 陽性細胞の比率が全例で高く，とくに 3 例 (Y.I., S.M., T.N.) は著明に増加していた. 一方, OKT 4 陽性細胞の比率忙 2 例 (K.K., C.Y.) を除き正常 であり，したがって OKT 4/OKT 8 比は全例低值を示し た.この成績は, in vitro に扔ける suppressor T 細胞活 性增加を支持するものであろう.

In vitro における免疫グロブリン産生状態を検討する と, 全症例とも IgA, IgG は健常者と同程度に生合成さ れ, IgM のみ低下していた. IgMに関しては患者 B 細胞 と健常者 $\mathrm{T}$ 細胞を組み合わせた反応系では十分量の IgM を産生することから，患者 B リンパ球の内的欠損は ないと推定された. また，健常者 $\mathrm{B}$ 細胞と㭧者 $\mathrm{T}$ 細胞を 組み合わせると，IgM 産生が著明に低下したことと，予 めX線照射し suppressor 機能を除いた患者 $\mathrm{T}$ 細胞を患 者 $\mathrm{B}$ 細胞あるいは正常 $\mathrm{B}$ 細胞と組み合わせると, 正常量 の IgM が産生されることから, IgM 特異的 suppressor T細胞活性の増強が推定された. したがって，正常 $\mathrm{T}$ 細 胞の存在下では患者 $\mathrm{B}$ リンパ球は $\operatorname{IgM}$ 分泌細胞へ分化 する能力を有すると考えられる. 一定数の健常者 B 細胞 に各種濃度の $\mathrm{X}$ 線照射患者 $\mathrm{T}$ 細胞を添加すると, $\mathrm{T}$ 細胞 の濃度に比例して IgA, IgG, IgM の産生が増加した. 一方，X線照射をしない患者 $\mathrm{T}$ 細胞を加えると濃度に関 係なくIgM 産生はみられなかった.これらの成績から， IgM 欠損の病態は IgM 特異的 suppressor T 細胞の機 能異常によるものと考えられた.

SLE では，一般的に OKT 8 陽性細胞の減少が報告さ れているが21)，本研究の 3 例では增加しており, 通常の SLE と対照的であった. SLE においてはB 細胞の機能 過剩状態がみられ，原因として suppressor $\mathrm{T}$ 細胞の機 能欠宿が指摘されている.これにも B 細胞異常に依存し た suppressor $\mathrm{T}$ 細胞異常, $\mathrm{T}$ 細胞固有の異常, および OKT 4 陽性細胞の IL 2 (interleukin 2) 産生不能があ る. IgM 欠損症合併 SLE では B 細胞機能異常や OKT 4 陽性細胞の異常は in vitro でも認められず，T細胞固有 の異常が考えられ，IgM 欠損をきたした suppressor $\mathrm{T}$ 細胞異常のために，B細胞機能が抑制され，この結果と して感染症を併発したものと考えられる。また, SLE で は自己リンパ球混合培垗反応 (autologous mixed lymphocyte reaction : AMLR) の低下がみられ, これも T 細胞の正常の分化の中断を示するので, 免疫系の恒常性
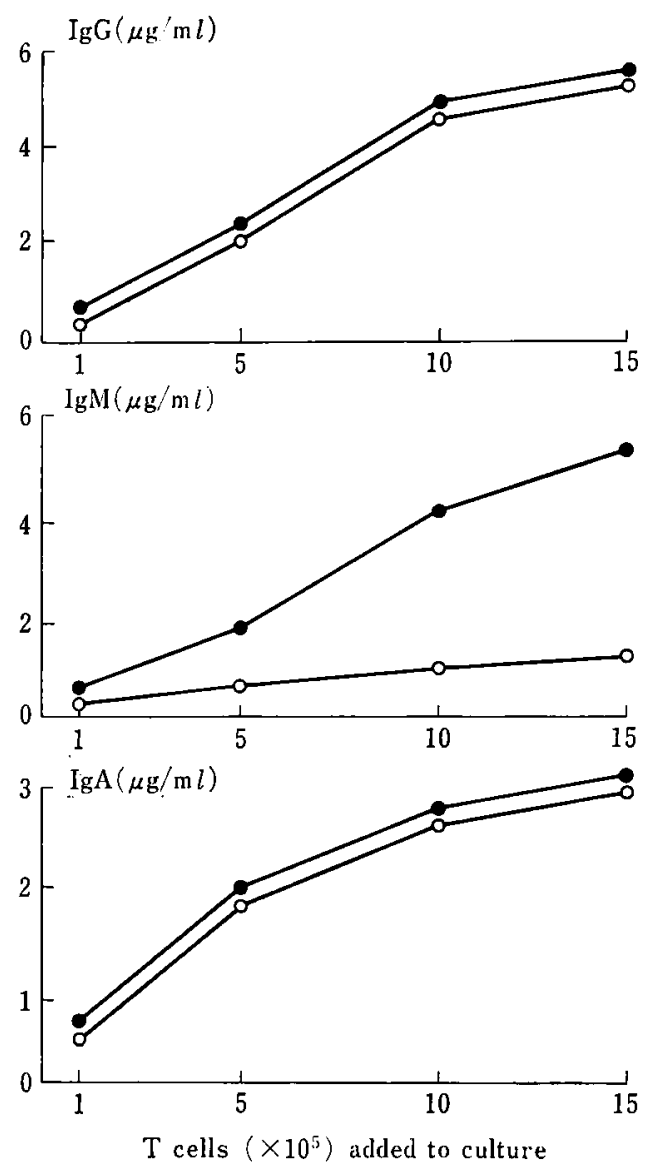

$(\mathrm{O}-\mathrm{O})$; non-irradiated $\mathrm{T}$ cells of patient $\mathrm{M} . \mathrm{F}$. (๑- ); irradiated $T$ cells of patient M. F.

图 2 Ig synthesis in vitro

Synthesis of IgA, IgG and IgM as a function of $\mathrm{T}$ cell concentration. A fixed number of $B$ cells $\left(5 \times 10^{5} / \mathrm{m} l\right)$ was co-cultured with varied numbers of $T$ cells. Values are means of three determinations.

が障害されていることを示している.こうした背景をも つSLEに，さらに suppressor T 細胞活性を高める因子 が作用して IgM 久損をきたしたと推定される.

原発性免疫不全症の中で頻度が高いIgA 欠損症の病 態については，多様性がみられていることはすでに報告 してきた ${ }^{2)}$. 寸なわち, (1) B 細胞の内的欠損, (2) IgA 特異的 helper $\mathrm{T}$ 細胞の機能低下, (3) IgA 特異的 suppressor $\mathrm{T}$ 細胞の活性増加，および, (4) B 細胞異常と suppressor $\mathrm{T}$ 細胞の活性增加を合併している 4 つの型 である. しかし，今回検討した 10 例の IgM 欠損症では B 細胞の異常はみられなかった。この原因を考えると， 
B 細胞の分化過程においてみられる heavy chain のク ラススイッチは $\mu, r, \varepsilon, \alpha$ の順に起こることが知られ ているが,この過程でB 細胞の内的欠損として $\mu$ 鎖の生 合成が障害されると，それにつうく $\mu$ 鎖以外人の免疫グ ロブリン合成も阻害され，液性免疫不全状態が生じ，幼 児期に淘汰された可能性もある. しかし最近, Ohno ら ${ }^{23)}$ は 4 例の IgM 欠損症を分析し, 2 例の末梢血で T cell のサプレッサー活性六進と IgM 特異的 B cell の反応 性の低下を報告しており，興味がもたれる.

また，染色体異常をもつ症例も報告されているた め 24,25)，全症例の染色体を調べたがいずれも異常を認め

1) Cunningham-Rundles, C., Pudifin, D.J., Armstrong, D. et al. : Selective IgA deficiency and neoplasia. VOX Sang, $38: 61 \sim 67,1980$.

2) Inoue, T., Okubo, H., Ikuta, T. et al. : Selective $\lg$ A deficiency-Analysis of Ig production in vitro. J. Clin. Immunol., $4: 235 \sim 241,1984$.

3) Cassidy, J.T., Nordby, G.L. : Human serum immunoglobulin concentrations: Prevalence of immunoglobulin deficiencies. J. Allerg. Clin. Immunol., $55:$ 35 48, 1975.

4) Hobbs, J.R., Milner, R.D.G., Watt, P.J. : Gamma-M deficiency predisposing to meningococcal septicemia. Br. Med. J., 4 : 583 586, 1967.

5) Ross, I.N., Thompson, R.A. : Selective IgM deficiency. J. Clin. Pathol., $29: 773 \sim 777,1976$.

6) Fauk, W.P., Kiyase, W.S., Cooper, M.D. et al. : Deficiency of IgM. Pediatrics, $47: 399 \sim$ 404, 1971.

7) Silver, H.K.B., Shuster, J., Gold, P. et al. : Leucoagglutinins and low IgM in a family with severe febrile illness. Clin. Immunol. Immunopathol., $1: 220 \sim 229,1973$.

8) Böyum, A. : Isolation of leukocyte from human blood. Scand. J. Clin. Invest., 21 (Suppl. 97): 9 89, 1968.

9) Bentwich, S., Douglas, S.D., Siegal, F.P. et al. : Human lymphocyte-sheep erythrocyte rosette formation: Some characteristics of the interaction. Clin. Immunol. Immunopathol., 1 : 511 522, 1973.

10) Kudo, J., Okubo, H., Ikuta, T. et al. : Immuno-
なかった。

\section{V. 結 語}

10 例の IgM 欠損症を報告した. 10 例中 3 例が SLE, 1 例が RA を基碄疾患としておう，全例ともに感染症が 重症化しやすい傾向を示した．また，in vitro における 免疫グロブリン産生能を細胞レベルで解析し，全症例に IgM 特異的 suppressor $\mathrm{T}$ 細胞活性の増強が証明された。 モノクローナル抗体による表面マーカーの検索では，全 症例に OKT 4/OKT 8 比の低下を認め, in vitro の結果 を支持する成績が得られた。

献

regulatory function of human acute phase reactive (APR) proteins. Biomed. Res., $3: 422 \sim$ 428, 1982.

11) Moore, V., Putnam, F.W. : Disulfide peptides and glycopeptides of a human IgA myeloma globulin. Biochemistry, $12: 2361 \sim 2370,1973$.

12) Onoue, K., Yagi, Y., Pressman, D. : Multiplicity of antibody proteins in rabbit anti-p-azobenzenearsonate sera. J. Immunol., $92: 173 \sim$ 184, 1973.

13) Putnam, F.W., Kozuru, M., Easley, C.W. : Structural studies of the immunoglobulins. IV. Heavy and light chains of the IgM pathological macroglobulins. J. Biol. Chem., $242: 2435 \sim$ 2446, 1967.

14) Nisonoff, A., Wissler, F.C., Lipman, L.N. et al. : Separation of univalent fragments from the divalent rabbit antibody molecule by reduction of disulfide bonds. Arch. Biochem. Biophys., $89: 230 \sim 244,1960$.

15) Endo, M., Kaneshige, H., Tomio, J. : Selective IgM deficiency. A case study. Tokai Exp. Clin. Med., $6: 327 \sim 331,1981$.

16) Vogelzang, N.J., Corwin, H., Finlay, J.L. : Clear cell sarcoma and selective IgM deficiency. A case report. Cancer, $47: 234 \sim 238,1982$.

17) Matsushita, S., Inoue, T., Okubo, H. : A case of selective IgM deficiency: Isotype specific suppressor T lymphocytes. Jap. J. Med., 23 : 149 151, 1984.

18) Delaconcha, E.G., Garcia-Rodrigues, C.M., 
Zabay, J.M. et al. : Functional assessment of $\mathrm{T}$ and $\mathrm{B}$ lymphocytes in patients with selective IgM deficiency. Clin. Exp. Immunol., $49: 670 \sim$ 676, 1982.

19) Gupta, S., Good, R.A. : Subpopulations of human T lymphocytes. V. T lymphocytes with receptors for immunoglobulin $\mathrm{M}$ or $\mathrm{G}$ in patients with primary immunodeficiency disorders. Clin. Immunol. Immunopathol., 11 : 292 302, 1978.

20) Inoue, T., Ikuta, T., Kudo, J. et al. : Abnormalities of IgA specific $B$ and suppressor $T$ cell functions in a patient with selective IgA deficiency and systemic lupus erythematosus. Jap. J. Clin. Immunol., $6: 96 \sim 101,1983$.

21) Morimoto, C., Reinherz, E.L., Schlossman, S.F. et al. : Alterations in immunoregulatory $\mathrm{T}$ cell subsets in active systemic lupus erythematosus.
J. Clin. Invest., $66: 1171 \sim 1176,1980$.

22) Sakane, T., Steinberg, A.D., Green, I. : Failure of autologous mixed lymphocyte reactions between $T$ and non- $T$ cells in patients with systemic lupus erythematosus. Proc. Natl. Acad. Sci. USA, $75: 3464 \sim 3468,1978$.

23) Ohno, T., Inaba, M., Kuribayashi, K. et al. : Selective IgM deficiency in adults : phenotypically and functionally altered profiles of peripheral blood lymphocytes. Clin. exp. Immunol., $68: 630 \sim 637,1987$.

24) Haddad, Z.H., Allen, R.F., Towner, J.W. et al. : IgA, IgM, and partial deletion of chromosome 18. Lancet, $1: 678,1969$.

25) Ostergaard, P.A. : A girl with recurrent infections, low IgM and an abnormal chromosome number 1. Acta. Pediat. Scand., $62: 211 \sim 215$, 1973. 